\title{
PERSEPSI SISWA KELAS X TERHADAP PENYELENGGARAAN PENDIDIKAN BERBASIS SISTEM KREDIT SEMESTER (SKS) DI SMA NEGERI BALI MANDARA TAHUN PELAJARAN 2017/2018
}

\author{
Siti Qomariyah ${ }^{1}$, lyus Akhmad Haris², Kadek Rai Suwena ${ }^{3}$ \\ Program Studi Pendidikan Ekonomi \\ Universitas Pendidikan Ganesha \\ Singaraja, Indonesia
e-mail: \{sitigomariyah872@gmail.com¹ , ivusharis55@gmail.com² kadek suwena@yahoo.co.id $\left.{ }^{3}\right\}$

\begin{abstract}
Abstrak
Penelitian ini bertujuan untuk mengetahui persepsi siswa kelas $X$ terhadap penyelenggaraan pendidikan berbasis sistem kredit semester (SKS) di SMA Negeri Bali Mandara tahun pelajaran 2017/2018 dan penerapan pendidikan berbasis SKS di SMA Negeri Bali Mandara. Jenis penelitian ini adalah penelitian deskriptif dengan pendekatan kuantitatif. Populasi dalam penelitian ini adalah seluruh siswa kelas X SMA Negeri Bali Mandara tahun pelajaran 2017/2018 yang berjumlah 129 siswa dan sampel ditentukan sebanyak 98 siswa yang diambil dengan menggunakan teknik proportional random sampling. Data dikumpulkan dengan metode kuesioner dan wawancara, analisis data yang digunakan adalah analisis deskriptif. Hasil penelitian menunjukkan bahwa, persepsi siswa kelas $\mathrm{X}$ terhadap penyelenggaraan pendidikan berbasis sistem kredit semester (SKS) di SMA Negeri Bali Mandara tahun pelajaran 2017/2018 adalah setuju dengan adanya penyelenggaraan pendidikan berbasis SKS yang diterapkan sekolah. Penerapan pendidikan berbasis sistem kredit semester (SKS) di SMA Negeri Bali Mandara terselenggara dengan cukup baik. Hal ini dikarenakan adanya faktorfaktor yang menjadi pendukung terkuat terselenggaranya program SKS tersebut. Faktor-faktor tersebut meliputi sarana dan prasarana yang memadai, dan sumber daya manusia (SDM) yang juga sangat welcome dengan adanya setiap perubahan sehingga bisa dengan mudah beradaptasi dengan sistem pendidikan yang baru.
\end{abstract}

Kata kunci: persepsi siswa, sistem kredit semester

\begin{abstract}
This study aims to determine the perceptions of the tenth grade students toward semester credit system based education (SKS) in SMA Negeri Bali Mandara in academic year 2017/2018 and also to determine the implementation of SKS based education in SMA Negeri Bali Mandara. This type of research belongs to descriptive research with a quantitative approach. The populations in this study were all students of tenth grade students in SMA Negeri Bali Mandara in academic year 2017/2018 consist of 129 students and 98 students were taken as the sample of the study. The sample was determined by using proportional random sampling technique. The data was collected through an interview method and questionnaire, meanwhile the data analysis used was descriptive analysis. The results shows that the perception of the tenth grade students about the implementation of semester credit system based education (SKS) in SMA Bali Mandara in academic year 2017/2018 is agreed with the implementation of SKS based education that applied in the school. The semester credit system based education (SKS) in SMA Bali Mandara was done well since there were some factors which was support the implementation of the credit system based education (SKS) program. These factors including good facilities and infrastructure, and human resources (HR) that are also very welcome with each change so that they can easily adapt to the new education system.
\end{abstract}

Keywords: student perceptions, semester credit system 


\section{PENDAHULUAN}

Pendidikan menjadi salah satu aspek yang sangat penting dan menentukan dalam upaya meningkatkan kemajuan suatu bangsa. Dalam hal ini, sumber daya yang dimiliki utamanya sumber daya manusia (SDM) harus terus dikembangkan kualitasnya. Hal tersebut bertujuan untuk mencapai kemajuan pada berbagai bidang yang diprioritaskan dan mengingat bahwa dari masa ke masa pendidikan terus berkembang secara progresif mengikuti perubahan peradaban manusia.

Saat ini, sistem penyelenggaraan pendidikan di Indonesia baik pada satuan pendidikan dasar maupun menengah secara umum masih menggunakan sistem paket. Dalam penerapan sistem paket, semua peserta didik mendapatkan pembelajaran yang sama berdasarkan ketentuan yang sudah ditetapkan sekolah. Selain itu, lamanya waktu studi antara peserta didik yang satu dengan peserta didik lainnya juga sama, tanpa memandang perbedaan kemampuan intelektual yang dimiliki oleh peserta didik. Hal ini tentunya berseberangan dengan amanat pendidikan nasional yang termuat dalam Undang-Undang Nomor 20 Tahun 2003 tentang Sistem Pendidikan Nasional pada Pasal 12 Ayat 1 (b) yang menyatakan bahwa "setiap peserta didik pada setiap satuan pendidikan berhak mendapatkan pelayanan pendidikan sesuai dengan bakat, minat, dan kemampuannya". Selanjutnya pada butir (f) dinyatakan pula bahwa "peserta didik pada setiap satuan pendidikan berhak menyelesaikan pendidikan sesuai dengan kecepatan belajar masing-masing dan tidak menyimpang dari ketentuan batas waktu yang ditetapkan".

Penyelenggaraan

pendidikan dengan sistem paket berdampak bagi peserta didik yang memiliki kemampuan intelektual tinggi untuk mempersingkat masa studinya di Sekolah. Sementara itu, bagi peserta didik yang memiliki kemampuan intelektual rendah, akan merasa sulit dalam mengikuti perkembangan pembelajaran peserta didik dengan intelektual tinggi tersebut (Ati, 2015). Untuk memperkecil dampak yang dapat ditimbulkan dari penyelenggaraan pendidikan dengan sistem paket, diperlukan sebuah sistem pendidikan yang mampu merealisasikan tujuan pendidikan nasional sebagaimana termuat dalam Undang-Undang Nomor 20 Tahun 2003 tersebut.

Sistem Kredit Semester (SKS) merupakan jawaban dari permasalahan yang ada pada sistem paket dan menjadi salah satu inovasi dalam penyelenggaraan pendidikan di Sekolah. Menurut Peraturan Menteri Pendidikan dan Kebudayaan Nomor 158 Tahun 2014 menyatakan bahwa "sistem kredit semester yang selanjutnya disebut SKS adalah bentuk penyelenggaraan pendidikan yang peserta didiknya menentukan jumlah beban belajar dan mata pelajaran yang diikuti setiap semester pada satuan pendidikan sesuai dengan bakat, minat, dan kemampuan/kecepatan belajar".

Penyelenggaraan pendidikan berbasis SKS memungkinkan peserta didik untuk dapat lebih mengembangkan potensi, minat dan bakatnya sesuai dengan kapasitas yang dimilikinya. Selain itu, penyelenggaraan pendidikan berbasis SKS juga memberikan peluang bagi peserta didik yang memiliki kemampuan intelektual tinggi untuk mempersingkat waktu studinya. Melalui penyelenggaraan SKS, peserta didik dimungkinkan dapat menyelesaikan studi dengan waktu minimal 2 tahun atau setara dengan empat semester (Rusman, 2017). Hal ini tentu berbeda dengan waktu yang umumnya ditempuh pada sekolah-sekolah reguler yang belum menerapkan sistem ini.

Pendidikan berbasis SKS diselenggarakan melalui pengorganisasian pembelajaran yang bervariasi dan pengelolaan waktu belajar yang fleksibel (Direktorat Jenderal Pendidikan Dasar dan Menengah Kementerian Pendidikan dan Kebudayaan, 2017).

Salah satu sekolah di Bali yang menerapkan pendidikan berbasis SKS ini adalah SMA Negeri Bali Mandara yang berlokasi di Jalan Air Sanih, Desa Kubutambahan Kecamatan Kubutambahan Kabupaten Buleleng, Bali. Penyelenggaraan SKS di SMA Negeri Bali 
Mandara dimulai dari tahun 2011. Berbagai kesiapan yang telah dimiliki oleh Sekolah dalam menunjang optimalisasi penyelenggaraan SKS antara lain pelayanan yang terintegrasi, tenaga pendidik yang berkompeten, sarana prasarana yang memadai, serta manajemen sekolah yang baik.

Penyelenggaraan SKS yang diterapkan sekolah haruslah senantiasa mendapat dukungan dari berbagai unsur yang terdapat dalam sekolah khususnya dukungan dari siswa. Siswa merupakan salah satu unsur terpenting dalam suatu penyelenggaraan pendidikan. Hal ini dikarenakan tanpa adanya siswa, kegiatan pembelajaran di Sekolah tidak dapat terlaksana. Berkaitan dengan hal tersebut, setiap siswa tentunya mempunyai pengalaman dan perasaan yang berbedabeda selama menjalani pendidikan dengan sistem kredit semester ini. Pengalaman belajar yang dijalani dan dirasakan saat ini sangatlah berbeda dengan pendidikan yang ditempuh pada jenjang sebelumnya (SMP/MTs). Rasa ketertarikan, senang atau tidaknya siswa atas penerapan SKS ini pun juga tentu berbeda. Selain itu, dengan penerapan SKS di Sekolah apakah siswa merasa bahwa kemampuan berpikir atau daya intelektualnya jauh lebih meningkat atau tidak, dan apakah motivasi belajarnya meningkat pula, hal-hal tersebut perlu diketahui mengingat bahwa siswa merupakan sasaran utama dalam proses belajar mengajar di Sekolah. Hal-hal tersebut dapat diketahui melalui tanggapan (response) yang diberikan siswa atas penyelenggaraan SKS tersebut.

Tanggapan (response) dapat juga disebut sebagai persepsi, yang mana persepsi merupakan suatu proses yang didahului oleh proses penginderaan dimana seseorang menerima stimulus melalui alat indera atau reseptornya (Walgito, 2010). Persepsi juga sering dimaknai sebagai pandangan mengenai bagaimana seseorang dalam mengartikan sesuatu. Menurut Thoha (2003:145), proses terbentuknya persepsi melalui beberapa tahap yang meliputi stimulus atau rangsangan, registrasi, dan interpretasi. Sementara itu, menurut Walgito (2003), terdapat dua faktor yang dapat mempengaruhi seseorang dalam mengadakan persepsi terhadap suatu objek. Pertama, faktor internal yang merupakan faktor yang berasal dari dalam diri individu yang berhubungan dengan aspek psikologis. Kedua, faktor eksternal yang merupakan faktor yang berasal dari luar individu yang berhubungan dengan objek dan lingkungan.

Berkaitan dengan hal tersebut, peneliti melakukan penelitian pada siswa kelas $X$ dikarenakan semua siswanya mengalami, mengikuti, dan merasakan program pendidikan berbasis SKS untuk pertama kalinya, setelah sebelumnya melewati program pendidikan di jenjang menengah pertama (SMP/MTs) yang tidak menerapkan sistem ini. Peralihan fase yang dirasakan dan dijalani oleh setiap peserta didik kelas $X$ dalam menempuh pendidikan dari sistem paket menuju sistem kredit semester (SKS) juga sangat berbeda utamanya dalam penetapan muatan pembelajaran. Dalam sistem paket, muatan pembelajaran telah ditetapkan oleh Sekolah, sebaliknya dalam SKS peserta didiklah yang menjadi penentu dalam menentukan mata pelajaran yang akan diambil di setiap semesternya. Kemampuan dan kecepatan belajar peserta didiklah yang dijadikan sebagai acuannya sehingga perbedaan dalam pengambilan jumlah beban belajar antar peserta didik lumrah terjadi.

Selain itu, berdasarkan hasil observasi awal, diketahui bahwa kelas $\mathrm{X}$ merupakan kelas yang paling heterogen bila dibandingkan dengan kelas XI dan XII. Heterogen dalam hal ini bermakna bahwa dalam setiap kelas yang berada di jenjang kelas $X$, terdiri dari berbagai jenis karakteristik siswa.

Berdasarkan latar belakang masalah di atas, maka peneliti tertarik untuk mengetahui yaitu pertama, persepsi siswa kelas $X$ terhadap penyelenggaraan pendidikan berbasis sistem kredit semester (SKS) di SMA Negeri Bali Mandara tahun pelajaran 2017/2018. Kedua, penerapan pendidikan berbasis sistem kredit semester (SKS) di SMA Negeri Bali Mandara. 


\section{METODE PENELITIAN}

Jenis penelitian yang digunakan adalah deskriptif dengan pendekatan kuantitatif. Penelitian ini tidak dimaksudkan untuk menguji hipotesis, melainkan untuk menjawab pertanyaan yang termuat dalam rumusan masalah penelitian.

Menurut Arikunto (2006:130) "populasi adalah keseluruhan subjek penelitian." Populasi dalam penelitian ini adalah seluruh siswa kelas X SMA Negeri Bali Mandara tahun pelajaran 2017/2018 yang berjumlah 129 orang. Sampel adalah sebagian atau wakil populasi yang diteliti (Arikunto, 2006). Teknik pengambilan sampel yang digunakan dalam penelitian ini adalah proportional random sampling. Menurut Arikunto (2006), untuk memperoleh sampel yang representatif maka pengambilan subjek dari setiap kelas ditentukan seimbang atau sebanding dengan banyaknya subjek dalam masingmasing kelas. Penentuan jumlah sampel menggunakan rumus Slovin dilakukan dengan perhitungan jumlah populasi sebanyak 129 siswa, dan jumlah sampel diperoleh sebanyak 97,73 yang dibulatkan menjadi 98 siswa.

Jenis data yang digunakan dalam penelitian ini adalah data kualitatif dan data kuantitatif. Data kualitatif merupakan data informasi yang diperoleh melalui kegiatan wawancara dan data kuantitatif merupakan data informasi berupa angka yang diperoleh dari penyebaran kuesioner kepada responden.

Jenis data menurut sumbernya dalam penelitian ini menggunakan data primer dan data sekunder. Data primer dalam penelitian ini berupa skor hasil kuesioner dari jawaban responden dan hasil wawancara. Sementara itu, data sekunder dalam penelitian ini adalah data berupa nama dan jumlah siswa kelas $X$ tahun pelajaran $2017 / 2018$.

Adapun metode pengumpulan data yang digunakan dalam penelitian ini yaitu kuesioner dan wawancara. Kuesioner merupakan teknik pengumpulan data yang dilakukan dengan cara memberikan serangkaian pertanyaan atau pernyataan tertulis kepada responden untuk dijawab olehnya.
Kuesioner dalam penelitian ini digunakan untuk mendapatkan data terkait persepsi siswa terhadap penyelenggaraan pendidikan berbasis SKS yang diterapkan sekolah. Sementara itu, dalam penelitian ini, peneliti menerapkan jenis wawancara terstruktur yang mana peneliti menyusun dan menetapkan sendiri pertanyaanpertanyaan yang nantinya akan diajukan kepada wakasek bidang kurikulum selaku subjek penelitian.

Instrumen penelitian yang digunakan adalah kuesioner. Kuesioner dirancang menggunakan skala likert dengan lima alternatif jawaban yang meliputi sangat setuju (SS), setuju (S), kurang setuju (KS), tidak setuju (TS), dan sangat tidak setuju (STS). Pengujian instrumen dalam penelitian ini menggunakan uji validitas dan uji reliabilitas. Uji validitas merupakan suatu ukuran yang menunjukkan tingkat kevalidan suatu instrumen. Suatu instrumen dikatakan valid apabila $r_{\text {hitung }}>$ $r_{\text {tabel}}$, dan sebaliknya jika $r_{\text {hitung }}<r_{\text {tabel }}$ maka instrumen dikatakan tidak valid (Sugiyono, 2009). Uji validitas dalam penelitian ini dilakukan di SMA Negeri 2 Semarapura yang berlokasi di Jalan Dewi Sartika No 16, Semarapura. Hal ini didasarkan pada pertimbangan bahwa sekolah ini merupakan salah satu diantara dua sekolah di Bali yang menerapkan pendidikan berbasis SKS selain SMA Negeri Bali Mandara. Proses pengolahan data untuk uji validitas menggunakan teknik analisis korelasi product moment dengan menggunakan bantuan SPSS (Statistic Product and Service Solution) versi 16.0 for windows. Sedangkan uji reliabilitas merupakan ukuran yang menunjukkan konsistensi dari alat ukur dalam mengukur gejala yang sama pada waktu yang berbeda. Uji reliabilitas dihitung dengan menggunakan uji Cronbach's Alpha melalui program SPSS 16.0 for Windows.

Dalam menganalisa persepsi siswa kelas $\mathrm{X}$ terhadap penyelenggaraan SKS, peneliti menggunakan tiga langkah analisis data yaitu pertama, menentukan jumlah skor tertinggi dan terendah dari masing-masing indikator yang ada. Kedua, menentukan interval masing-masing kategori yang ada pada setiap indikator. 
Ketiga, menentukan rentang skor persepsi siswa, dan penarikan kesimpulan.

Selain itu dalam penelitian ini, peneliti juga menggunakan analisis data wawancara dengan berpedoman pada empat langkah analisis data yang dikemukakan oleh Bungin (2003) yaitu pertama, pengumpulan data (data collection) dengan melakukan wawancara kepada Wakasek bidang kurikulum SMA Negeri Bali Mandara, yaitu Bapak I Kadek Darsika Aryanta, S.Pd., M.Pd. Kedua, reduksi data (data reduction) yang merupakan kegiatan pengelolaan data yang didalamnya meliputi kegiatan mengikhtiarkan data selengkap mungkin dan memilahnya ke dalam satuan konsep, kategori dan tema tertentu. Ketiga, penyajian data (data display) yang merupakan kegiatan mendeskripsikan sekumpulan informasi yang membantu peneliti dalam penarikan kesimpulan dan pengambilan tindakan. Penyajian data dapat berbentuk teks naratif atau sinopsis, matriks, tabel dan bentuk lainnya.
Keempat, penegasan kesimpulan dan verifikasi (conclution drawing and verifying) yang merupakan kegiatan akhir dari proses analisis data. Penarikan kesimpulan dan verifikasi data dilakukan dengan mencari makna data yang telah disajikan sebelumnya pada tahap data display.

\section{HASIL DAN PEMBAHASAN Hasil Penelitian}

Berdasarkan data hasil penelitian mengenai persepsi siswa kelas $X$ terhadap pendidikan berbasis SKS yang diperoleh peneliti melalui penyebaran kuesioner terhadap 98 responden diperoleh hasil akhir bahwa siswa setuju dengan adanya penyelenggaraan pendidikan berbasis SKS yang diterapkan sekolah. Adapun rincian mengenai hasil penelitian terkait dengan persepsi siswa kelas $X$ terhadap pendidikan berbasis SKS di SMA Negeri Bali Mandara ditinjau dari masing-masing dimensi persepsi dapat dilihat pada tabel 1, 2 dan 3 berikut ini.

Tabel 1. Persepsi Siswa terhadap Penyelenggaraan Pendidikan Berbasis SKS di SMA Negeri Bali Mandara Ditinjau dari Dimensi Psikologis

\begin{tabular}{cccc}
\hline Indikator & Skor & Skala Interval & Kategori \\
\hline $\begin{array}{c}\text { Berpedoman pada } \\
\text { pengalaman siswa } \\
\text { sebelumnaa }\end{array}$ & 1.264 & $1.234,8-1.470$ & Sangat Setuju \\
\hline $\begin{array}{c}\text { Perasaan senang } \\
\text { dan ketertarikan } \\
\text { siswa }\end{array}$ & 1.289 & $1.234,8-1.470$ & Sangat Setuju \\
\hline $\begin{array}{c}\text { Meningkatkan } \\
\text { kemampuan } \\
\text { berpikir siswa }\end{array}$ & 845 & $823,2-980$ & Sangat Setuju \\
\hline $\begin{array}{c}\text { Meningkatkan } \\
\text { motivasi belajar } \\
\text { siswa }\end{array}$ & 1.748 & $1.646,4-1.960$ & Sangat Setuju \\
\hline Skor total & 5.146 & $4.939,2-5.880$ & Sangat Setuju \\
\hline
\end{tabular}

Tabel 2. Persepsi Siswa terhadap Penyelenggaraan Pendidikan Berbasis SKS di SMA Negeri Bali Mandara Ditinjau dari Dimensi Objek (Pendidikan Berbasis SKS)

\begin{tabular}{cccc}
\hline Indikator & Skor & Skala Interval & Kategori \\
\hline $\begin{array}{c}\text { Kegiatan } \\
\text { pembelajaran }\end{array}$ & 857 & $823,2-980$ & Sangat Setuju \\
\hline Beban belajar & 1.306 & $1.234,8-1.470$ & Sangat Setuju \\
\hline UKBM & 1.308 & $1.234,8-1.470$ & Sangat Setuju \\
\hline Masa studi & 822 & $666,4-823,1$ & Setuju \\
\hline Skor total & 4.293 & $4.116-4.900$ & Sangat Setuju \\
\hline
\end{tabular}


Tabel 3. Persepsi Siswa terhadap Penyelenggaraan Pendidikan Berbasis SKS di SMA Negeri Bali Mandara Ditinjau dari Dimensi Lingkungan

\begin{tabular}{cccc}
\hline Indikator & Skor & Skala Interval & Kategori \\
\hline Tempat & 886 & $823,2-980$ & Sangat Setuju \\
\hline Suasana & 843 & $823,2-980$ & Sangat Setuju \\
\hline $\begin{array}{c}\text { Sarana dan } \\
\text { prasarana }\end{array}$ & 880 & $823,2-980$ & Sangat Setuju \\
\hline Skor total & 2.609 & $2.469,6-2.940$ & Sangat Setuju \\
\hline
\end{tabular}

Berdasarkan pada tabel 1 di atas, dengan kategori sangat setuju, dan pada maka dapat dijelaskan bahwa persepsi tabel 3 dapat dijelaskan bahwa persepsi siswa terhadap penyelenggaraan pendidikan berbasis SKS ditinjau dari dimensi psikologis memiliki skor total 5.146 masuk dalam rentang skor 4.939,2 - 5.880 dengan kategori sangat setuju. Sementara itu, pada tabel 2 dapat dijelaskan bahwa persepsi siswa terhadap penyelenggaraan pendidikan berbasis SKS ditinjau dari dimensi objek yang dipersepsikan memiliki skor total 4.293 masuk dalam rentang skor $4.116-4.900$ siswa terhadap penyelenggaraan pendidikan berbasis SKS ditinjau dari dimensi lingkungan memiliki skor total 2.609 masuk dalam rentang skor 2.469,6 -2.940 dengan kategori sangat setuju.

Berikut ini disajikan tabel persentase mengenai persepsi siswa terhadap penyelenggaraan pendidikan berbasis SKS di SMA Negeri Bali Mandara yang peneliti gunakan sebagai acuan dalam menarik kesimpulan.

Tabel 4. Persentase Persepsi Siswa terhadap Penyelenggaraan Pendidikan Berbasis SKS di SMA Negeri Bali Mandara

\begin{tabular}{|c|c|c|c|c|c|c|}
\hline \multirow{2}{*}{ Dimensi } & \multirow{2}{*}{ Indikator } & \multicolumn{5}{|c|}{ Persentase } \\
\hline & & SS & $\mathrm{S}$ & $\mathrm{KS}$ & TS & STS \\
\hline \multirow{5}{*}{ Psikologis } & $\begin{array}{l}\text { Berpedoman pada } \\
\text { pengalaman siswa } \\
\text { sebelumnya }\end{array}$ & $32,99 \%$ & $64,29 \%$ & $2,72 \%$ & $0 \%$ & $0 \%$ \\
\hline & $\begin{array}{c}\text { Perasaan senang } \\
\text { dan ketertarikan } \\
\text { siswa }\end{array}$ & $38,78 \%$ & $60,88 \%$ & $0,34 \%$ & $0 \%$ & $0 \%$ \\
\hline & $\begin{array}{c}\text { Meningkatkan } \\
\text { kemampuan berpikir } \\
\text { siswa }\end{array}$ & $33,67 \%$ & $63,78 \%$ & $2,55 \%$ & $0 \%$ & $0 \%$ \\
\hline & $\begin{array}{c}\text { Meningkatkan } \\
\text { motivasi belajar } \\
\text { siswa } \\
\end{array}$ & $46,68 \%$ & $52,55 \%$ & $0,77 \%$ & $0 \%$ & $0 \%$ \\
\hline & Total & $38,03 \%$ & $60,37 \%$ & $1,60 \%$ & $0 \%$ & $0 \%$ \\
\hline \multirow{4}{*}{$\begin{array}{c}\text { Objek } \\
\text { (pendidikan } \\
\text { berbasis } \\
\text { SKS) }\end{array}$} & $\begin{array}{c}\text { Kegiatan } \\
\text { pembelajaran }\end{array}$ & $38,78 \%$ & $59,18 \%$ & $2,04 \%$ & $0 \%$ & $0 \%$ \\
\hline & Beban belajar & $45,58 \%$ & $53,06 \%$ & $1,36 \%$ & $0 \%$ & $0 \%$ \\
\hline & UKBM & $47,28 \%$ & $50,34 \%$ & $2,38 \%$ & $0 \%$ & $0 \%$ \\
\hline & Masa studi & $26,53 \%$ & $66,33 \%$ & $7,14 \%$ & $0 \%$ & $0 \%$ \\
\hline & Total & $39,54 \%$ & $57,23 \%$ & $3,23 \%$ & $0 \%$ & $0 \%$ \\
\hline \multirow{3}{*}{ Lingkungan } & Tempat & $53,06 \%$ & $45,92 \%$ & $1,02 \%$ & $0 \%$ & $0 \%$ \\
\hline & Suasana & $32,65 \%$ & $64,80 \%$ & $2,55 \%$ & $0 \%$ & $0 \%$ \\
\hline & $\begin{array}{c}\text { Sarana dan } \\
\text { prasarana }\end{array}$ & $49,49 \%$ & $50 \%$ & $0,51 \%$ & $0 \%$ & $0 \%$ \\
\hline & Total & $45,07 \%$ & $53,57 \%$ & $1,36 \%$ & $0 \%$ & $0 \%$ \\
\hline
\end{tabular}


Berdasarkan pada tabel 4 di atas, maka dapat dijelaskan bahwa persepsi siswa kelas $X$ terhadap penyelenggaraan pendidikan berbasis SKS di SMA Negeri Bali Mandara pada dimensi psikologis yang memiliki nilai persentase dominan $60,37 \%$ masuk dalam kategori setuju (S). Sementara itu, dimensi objek (pendidikan berbasis SKS) memiliki nilai persentase dominan $57,23 \%$ masuk kategori setuju (S) dan dimensi lingkungan memiliki nilai persentase dominan $53,57 \%$ masuk dalam kategori setuju (S) pula.

Berdasarkan hasil wawancara yang telah dilakukan dengan Bapak I Kadek Darsika Aryanta, S.Pd., M.Pd. selaku Wakil Kepala Sekolah bidang kurikulum, peneliti dapat menjelaskan hal-hal sebagaimana berikut ini. Pertama, konsep penerapan pendidikan berbasis SKS di SMA Negeri Bali Mandara adalah kecepatan belajar. Hal ini bermakna bahwa kecepatan belajar siswa di Sekolah ditentukan oleh kemampuan yang dimilikinya. Kedua, terdapat beberapa faktor yang menjadi pendukung utama terselenggaranya program SKS di SMA Negeri Bali Mandara diantaranya sarana dan prasarana yang memadai dan sumber daya manusia (SDM) yang dimiliki turut mendukung terselenggaranya program SKS ini. Ketiga, terdapat pula beberapa kendala yang ditemukan dalam menyelenggarakan SKS yaitu tidak semua guru siap untuk mengikuti tuntutan SKS pola baru yang mana guru diharuskan merancang Unit Kegiatan Belajar Mandiri (UKBM). Keempat, bahwa secara umum, penerapan pendidikan berbasis sistem kredit semester (SKS) di SMA Negeri Bali Mandara tergolong sudah cukup baik dan terselenggara dengan optimal.

\section{Pembahasan}

Penyelenggaraan

pendidikan dengan sistem kredit semester (SKS) merupakan sebuah pengalaman baru yang dirasakan dan dijalani oleh para siswa di SMA Negeri Bali Mandara dalam menempuh program pendidikan. Hal ini dikarenakan pada jenjang pendidikan sebelumnya siswa hanya menjalani pendidikan dengan sistem paket. Namun walaupun demikian, siswa sangat antusias dan senang dengan adanya program SKS melebihi saat mereka menempuh pendidikan dengan sistem paket. Siswa merasakan manfaat-manfaat positif dari penyelenggaraan SKS seperti kemampuan berpikir dan motivasi belajarnya yang jauh lebih meningkat bila dibandingkan dengan saat siswa menjalani pendidikan dengan sistem paket. Siswa pun sangat berharap penyelenggaraan pendidikan berbasis SKS dapat terus berlanjut sehingga dapat menjadi pendekatan baru dan bermakna positif dalam pengembangan sistem penyelenggaraan pendidikan.

Dalam kegiatan pembelajaran dengan SKS, siswa menilai guru menjadi lebih kreatif dalam menyampaikan materi pelajaran didukung dengan metode mengajar yang lebih bervariasi pula. Kegiatan pembelajaran pun didukung dengan tersedianya Unit Kegiatan Belajar Mandiri (UKBM) yang dirancang oleh setiap guru pengampu mata pelajaran sebagai media pembelajaran yang dirasa efektif dalam membantu siswa untuk memahami materi pelajaran dengan cepat dan mudah. Penyelenggaraan SKS yang mengharuskan siswa untuk mengambil jumlah beban belajar di setiap semesternya pun menjadi motivasi tersendiri bagi siswa untuk terus meningkatkan Indeks Prestasi (IP) sehingga pada semester berikutnya siswa dapat mengambil jumlah beban belajar maksimum. Meninjau dari kategori siswa kelas $X$ yang heterogen utamanya dalam hal kemampuan intelektual, dimungkinkan adanya siswa yang dapat menempuh pendidikan dengan waktu minimal 2 tahun (4 semester) dan terdapat pula siswa yang menempuh pendidikan dengan batas waktu maksimal pendidikan 4 tahun (8 semester). Pernyataan peneliti ini didukung oleh hasil perhitungan kuesioner pada indikator masa studi yang mana sejumlah siswa terlihat kurang yakin dapat menempuh pendidikan lebih cepat bila melihat kemampuannya sendiri.

Penyelenggaraan SKS di SMA Negeri Bali Mandara telah didukung dengan tempat belajar yang bersih dan nyaman, sehingga suasana belajar yang tercipta pun sangat kondusif. Selain itu, 
sarana dan prasarana yang memadai dengan kondisi yang cukup terawat juga menjadi faktor pendukung terlaksananya penyelenggaraan SKS secara optimal. Harapan siswa untuk kedepannya yaitu agar kegiatan pembelajaran tidak hanya dilaksanakan di kelas saja melainkan dapat pula dilaksanakan di luar kelas agar sesekali siswa dapat menyegarkan pikiran dan belajar sambil menikmati alam bebas. Siswa juga berharap agar suasana yang kondusif dan nyaman dapat terus dibangun dan dipertahankan serta sarana prasarana dapat ditingkatkan lagi kualitas maupun kuantitasnya dalam mencapai optimalisasi penyelenggaraan SKS itu sendiri.

Berdasarkan penjelasan tersebut, maka dapat disimpulkan bahwa, secara umum siswa setuju dengan adanya penyelenggaraan pendidikan berbasis SKS yang diterapkan sekolah. Hal ini juga mengacu pada tabel persentase persepsi siswa kelas $X$ terhadap penyelenggaraan pendidikan berbasis SKS di SMA Negeri Bali Mandara yang menunjukkan bahwa pada dimensi psikologis memiliki nilai persentase dominan 60,37\% masuk dalam kategori setuju (S). Sementara itu, dimensi objek (pendidikan berbasis SKS) memiliki nilai persentase dominan $57,23 \%$ masuk dalam kategori setuju (S) dan dimensi lingkungan memiliki nilai persentase dominan $53,57 \%$ yang juga masuk dalam kategori setuju (S).

Adapun hasil penelitian yang diperoleh melalui kegiatan wawancara tentang penerapan pendidikan berbasis SKS di SMA Negeri Bali Mandara menunjukkan bahwa secara umum penerapan pendidikan berbasis SKS di SMA Negeri Bali Mandara terselenggara dengan cukup baik.

Konsep penerapan pendidikan berbasis SKS di SMA Negeri Bali Mandara adalah kecepatan belajar. $\mathrm{Hal}$ ini bermakna bahwa kecepatan belajar siswa di Sekolah ditentukan oleh kemampuan yang dimilikinya. Siswa yang memiliki kemampuan intelektual tinggi dapat mengambil jumlah beban belajar yang maksimum sehingga dapat mempercepat masa studinya dengan waktu minimal 2 tahun atau setara dengan 4 semester.
Sebaliknya, bagi siswa yang memiliki kemampuan intelektual sedang hingga kurang dapat mengambil jumlah beban belajar yang sesuai dengan kemampuannya dengan masa tempuh studi normal 3 tahun ( 6 semester) hingga masa studi maksimal yaitu 4 tahun (8 semester).

Terdapat beberapa faktor yang menjadi pendukung terselenggaranya program SKS di SMA Negeri Bali Mandara diantaranya sarana dan prasarana yang memadai seperti ruang kelas yang mencukupi dan fasilitas pendukung lainnya. Selain itu, sumber daya manusia (SDM) yang terdiri dari tenaga pendidik, tenaga pegawai, dan siswa juga sangat mendukung terselenggaranya program SKS ini. Semua pihak terkait juga dengan mudah beradaptasi atau menyesuaikan diri dengan sistem penyelenggaraan pendidikan yang baru.

Selain faktor pendukung, terdapat pula beberapa kendala yang ditemukan dalam menyelenggarakan SKS yaitu tidak semua guru siap untuk mengikuti tuntutan SKS pola baru yang mana guru diharuskan merancang Unit Kegiatan Belajar Mandiri (UKBM). Banyaknya UKBM yang harus dibuat pada setiap mata pelajaran dapat menjadi beban dan tantangan tersendiri bagi para guru untuk mengikuti perubahan dan pengembangan pola SKS yang baru.

Penyelenggaraan SKS nyatanya juga memberikan dampak bagi pihakpihak yang secara langsung menjadi penyokong utama terselenggaraanya pendidikan seperti sekolah, guru maupun siswa. Pertama, bagi sekolah, dampak yang dirasakan selama penyelenggaraan SKS tidaklah begitu berarti. Pengelolaan sekolah juga masih sama dengan sekolah pada umumnya, hanya saja terdapat beberapa penambahan pada bagian administrasi sekolah seperti pembuatan kartu rencana studi (KRS), kartu hasil studi (KHS), dan program mata pelajaran yang akan diambil oleh siswa pada setiap semesternya serta penginputan data-data terkait lainnya. Kedua, bagi guru, dampak yang dirasakan selama penyelenggaraan SKS yaitu semua guru diharuskan siap untuk mengikuti setiap perubahan dan 
pengembangan pola SKS yang baru dimana guru harus membuat Unit Kegiatan Belajar Mandiri (UKBM) pada setiap mata pelajaran yang diampunya. Selain itu, guru juga harus mampu menciptakan pembelajaran yang kreatif dan menyenangkan sehingga mencegah kebosanan siswa selama mengikuti kegiatan pembelajaran. Ketiga, bagi siswa, dampak yang dirasakan selama penyelenggaraan SKS terdiri dari dampak positif dan dampak negatif. Dampak positifnya adalah siswa dapat lebih mudah mengembangkan minat dan bakat sesuai dengan kemampuannya. Hal ini terwujud dalam fleksibilitas yang dimiliki SKS yang tidak menuntut siswa untuk mengambil jumlah beban belajar yang sama dengan siswa lainnya. Pengambilan beban belajar disesuaikan dengan kemampuan masingmasing siswa. Adapun dampak negatifnya tidaklah begitu berarti, hanya saja siswa terkadang merasa lelah karena banyaknya aktivitas yang dilakukan selama kegiatan pembelajaran ditambah lagi dengan banyaknya UKBM yang harus dikerjakan pada setiap mata pelajaran.

Mengacu pada penjelasan di atas, dapat disimpulkan bahwa penerapan pendidikan berbasis SKS di SMA Negeri Bali Mandara tergolong cukup baik terlepas dari kendala yang dijumpai selama penyelenggaraan SKS. Hal ini sejalan dengan hasil penelitian terkait persepsi siswa terhadap penyelenggaraan pendidikan berbasis SKS di SMA Negeri Bali Mandara yang menyatakan setuju dengan terselenggaranya program SKS ini dan turut mendukung keoptimalan penyelenggaraan SKS tersebut.

\section{SIMPULAN DAN SARAN Simpulan}

Berdasarkan hasil penelitian dan pembahasan maka dapat disimpulkan bahwa pertama, persepsi siswa kelas $X$ terhadap penyelenggaraan pendidikan berbasis sistem kredit semester (SKS) di SMA Negeri Bali Mandara tahun pelajaran 2017/2018 menunjukkan bahwa, ditinjau dari ketiga dimensi persepsi yakni psikologis, objek (pendidikan berbasis SKS), dan lingkungan menunjukkan bahwa, siswa setuju dengan adanya penyelenggaraan pendidikan berbasis sistem kredit semester (SKS) di SMA Negeri Bali Mandara. Hal tersebut terlihat dari persentase yang dimiliki masingmasing dimensi persepsi yang mana dimensi psikologis memiliki nilai persentase dominan 60,37\%, dimensi objek (pendidikan berbasis SKS) memiliki nilai persentase dominan $57,23 \%$, dan dimensi lingkungan memiliki nilai persentase dominan 53,57\% yang kesemuanya masuk dalam kategori setuju. Kedua, penerapan pendidikan berbasis sistem kredit semester (SKS) di SMA Negeri Bali Mandara terselenggara dengan cukup baik. Hal ini dikarenakan adanya faktor-faktor yang menjadi pendukung terkuat terselenggaranya program SKS tersebut. Faktor-faktor tersebut meliputi sarana dan prasarana yang memadai, dan sumber daya manusia (SDM) yang juga sangat welcome dengan adanya setiap perubahan sehingga bisa dengan mudah beradaptasi dengan sistem pendidikan yang baru.

\section{Saran}

Berdasarkan hasil penelitian, pembahasan dan simpulan, maka dapat diajukan saran yaitu pertama, bagi SMA Negeri Bali Mandara, penelitian ini dapat dijadikan sebagai bahan evaluasi bagi Sekolah untuk meningkatkan pengelolaan dan kebermanfaatan penyelenggaraan pendidikan berbasis SKS itu sendiri. Selain itu, bagi tenaga pendidik juga diharapkan agar terus meningkatkan kesiapan dalam menghadapi tuntutan dari setiap perubahan sistem penyelenggaraan pendidikan dan selalu menciptakan kegiatan pembelajaran yang kreatif dan menyenangkan agar siswa mempunyai keyakinan tersendiri bahwa SKS merupakan sistem penyelenggaraan pendidikan yang efektif dan efisien. Kedua, bagi kepentingan ilmiah dan peneliti lainnya. Bagi peneliti lain yang hendak melakukan penelitian serupa, disarankan dalam penelitian selanjutnya dapat menambahkan variabel lain, sehingga hasil penelitian dapat digeneralisasi secara luas. Selain itu, disarankan juga bagi peneliti lainnya untuk mampu menganalisis dan 
membandingkan antara penyelenggaraan SKS di suatu sekolah dengan sekolah lainnya yang juga menerapkan sistem ini.

\section{DAFTAR PUSTAKA}

Arikunto, Suharsimi. 2006. Prosedur Penelitian Suatu Pendekatan Praktik. Jakarta: Rineka Cipta.

Ati, Lutfi Mufti. 2015. "Implementasi Sistem Kredit Semester dan Dampaknya Terhadap Pembelajaran $P A I$ dan Budi Pekerti Kelas X di SMA Negeri 1 Kebumen". Tersedia pada http://digilib.uin-suka.ac.id/19690/ (Diakses tanggal 08 Maret 2018).

Bungin, Burhan. 2003. Analisis Data Penelitian Kualitatif Pemahaman Filosofis dan Metodologis ke Arah Penguasaan Model Aplikasi. Jakarta: PT Raja Grafindo Persada.

Depdiknas. 2008. Undang-Undang Nomor 20 Tahun 2003 tentang Sistem Pendidikan Nasional dan UndangUndang Nomor 14 Tahun 2005 tentang Guru dan Dosen. Jakarta: Transmedia Pustaka.

Direktorat Jenderal Pendidikan Dasar dan Menengah Kementerian Pendidikan dan Kebudayaan. 2017. Pedoman Penyelenggaraan Sistem Kredit Semester (SKS) di SMA. Jakarta: Direktur Pembinaan SMA.

Kemendikbud. 2014. Peraturan Menteri Pendidikan dan Kebudayaan Republik Indonesia Nomor 158 Tahun 2014 tentang Penyelenggaraan Sistem Kredit Semester pada Pendidikan Dasar dan Menengah. Jakarta: Menteri Pendidikan dan Kebudayaan.

Rusman. 2017. Belajar dan Pembelajaran Berorientasi Standar Proses Pendidikan. Jakarta: Kencana.

Sugiyono. 2009. Metode Penelitian Pendidikan (Pendekatan Kuantitatif, Kualitatif, dan $R$ \& D). Bandung: Alfabeta.

Thoha, Miftah. 2003. Perilaku Organisasi Konsep Dasar dan Aplikasinya. Jakarta: Raja Grafindo Persada. Walgito, Bimo. 2003. Psikologi Sosial (Suatu Pengantar). Yogyakarta: Andi Offset.

\section{--------. 2010. Pengantar Psikologi Umum. Yogyakarta: Andi Offset.}

